\title{
Addressing male sexual and reproductive health in the wake of COVID-19 outbreak
}

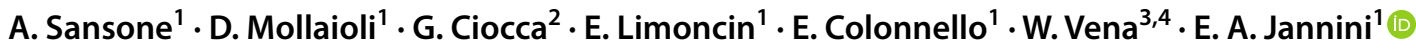

Received: 16 June 2020 / Accepted: 29 June 2020 / Published online: 13 July 2020

(c) The Author(s) 2020

\begin{abstract}
Purpose The COVID-19 pandemic, caused by the SARS-CoV-2, represents an unprecedented challenge for healthcare. COVID-19 features a state of hyperinflammation resulting in a "cytokine storm", which leads to severe complications, such as the development of micro-thrombosis and disseminated intravascular coagulation (DIC). Despite isolation measures, the number of affected patients is growing daily: as of June 12th, over 7.5 million cases have been confirmed worldwide, with more than 420,000 global deaths. Over 3.5 million patients have recovered from COVID-19; although this number is increasing by the day, great attention should be directed towards the possible long-term outcomes of the disease. Despite being a trivial matter for patients in intensive care units (ICUs), erectile dysfunction (ED) is a likely consequence of COVID-19 for survivors, and considering the high transmissibility of the infection and the higher contagion rates among elderly men, a worrying phenomenon for a large part of affected patients.

Methods A literature research on the possible mechanisms involved in the development of ED in COVID-19 survivors was performed.

Results Endothelial dysfunction, subclinical hypogonadism, psychological distress and impaired pulmonary hemodynamics all contribute to the potential onset of ED. Additionally, COVID-19 might exacerbate cardiovascular conditions; therefore, further increasing the risk of ED. Testicular function in COVID-19 patients requires careful investigation for the unclear association with testosterone deficiency and the possible consequences for reproductive health. Treatment with phosphodiesterase-5 (PDE5) inhibitors might be beneficial for both COVID-19 and ED.

Conclusion COVID-19 survivors might develop sexual and reproductive health issues. Andrological assessment and tailored treatments should be considered in the follow-up.
\end{abstract}

Keywords COVID-19 $\cdot$ SARS-CoV-2 $\cdot$ Erectile dysfunction $\cdot$ Sexual dysfunction $\cdot$ Male hypogonadism $\cdot$ Cardiovascular health

\section{Introduction}

The global outbreak of coronavirus disease (COVID-19) caused by the severe acute respiratory syndrome coronavirus

E. A. Jannini

eajannini@gmail.com

1 Chair of Endocrinology and Medical Sexology (ENDOSEX), Department of Systems Medicine, University of Rome Tor Vergata, via Montpellier 1, 00133 Rome, Italy

2 Department of Dynamic and Clinical Psychology, "Sapienza" University of Rome, Rome, Italy

3 Endocrinology, Diabetology and Andrology Unit, Humanitas Clinical and Research Center, IRCCS, Rozzano, MI, Italy

4 Department of Clinical Sciences and Community Health, University of Milan, Milano, Italy 2 (SARS-CoV-2) represents an unprecedented challenge for healthcare. Despite social distancing and isolation measures, the number of affected patients is growing daily. Hyperinflammation and immunosuppression are prominently featured in COVID-19 [1, 2], resulting in a cytokine storm [3] ultimately leading to development of micro-thrombosis and disseminated intravascular coagulation (DIC). This cytokine storm is strongly associated with the development of interstitial pneumonia (IP) [4]; however, although lungs are the primarily targeted organs, the cardiovascular system is globally affected. Evidence in this regard supports the 
notion that the exaggerated production of early response proinflammatory cytokines, such as tumor necrosis factor (TNF), interleukin-1 $\beta,-6$, and -10 (IL-1 $\beta$, IL-6, and IL-10, respectively), increases the risk of vascular hyperpermeability, possibly progressing to multiple organ failure and, ultimately, death [3]. The presence of vascular dysfunction at multiple levels, including pulmonary embolisms, alveolar hemorrhage, microangiopathy and vasculitis has been ascertained in post-mortem examination [5, 6]. Additionally, both venous and arterial thromboembolic complications, including endothelial inflammation, have been reported [7, 8]. Indeed, a growing body of evidence seems to support the theory that the endothelium is targeted by the SARS-CoV-2 [9]; most importantly, the endothelium expresses the protein angiotensin-converting enzyme 2 (ACE2) [10, 11], through which the virus can access host cells [12]. Endothelial dysfunction is, therefore, a pivotal determinant of COVID-19 symptoms $[13,14]$.

As of June 12th, 2020, more than 7.5 million COVID19 cases have been confirmed worldwide, with more than 420,000 lives lost due to the disease [15]. More than 3.5 million subjects have recovered from COVID-19; however, the long-term consequences of the disease are still largely unknown. Data from 2002-2004 epidemics of SARS suggest that cardiovascular sequelae, such as microangiopathy, cardiomyopathy and impaired endothelial function, are to be expected also in COVID-19 patients [5, 16]. However, while similarities with SARS have been identified, COVID-19 is largely more prevalent due to its high transmissibility, and its consequences, even for recovered patients, are likewise more worrying. Additionally, new evidence is suggesting that autoimmune conditions, such as type 1 diabetes mellitus, might be triggered by the onset of COVID-19 [17], therefore, worsening the risk profile for survivors.

These findings can be extremely relevant for male sexual health: indeed, based on these premises, there is quite enough evidence to hypothesize that consequences of COVID-19 can extend to sexual and reproductive health. We investigated the current literature to understand the longterm clinical complications for COVID-19 survivors, aiming to provide adequate information for clinicians to plan adequate and timely intervention measures.

\section{Testosterone and COVID-19: friend or foe?}

It is well established that ACE2 is the entry point for the SARS-CoV-2 in host cells [12]. In males, adult Leydig cells express this enzyme, therefore, suggesting that testicular damage can occur following infection [18]. Testicular damage in COVID-19 might, therefore, induce a state of hypogonadism as proven by decreased testosterone-to-LH ratio in patients with COVID-19, suggestive of impaired steroidogenesis resulting from subclinical testicular dysfunction
$[19,20]$. Post-mortem examinations of testicular tissue from 12 COVID-19 patients showed significantly reduced Leydig cells, as well as edema and inflammation in the interstitium [21]. A recent report on 31 male COVID-19 patients in Italy identified that some patients developed hypergonadotropic hypogonadism following the onset of the disease [22]. In the same study, lower levels of serum testosterone (total and free) acted as predictors of poor prognosis in SARSCoV-2 men [22]. Whether this state of hypogonadism is permanent or temporary is a question so far left unanswered. Testosterone acts as a modulator for endothelial function [23] and suppresses inflammation by increasing levels of anti-inflammatory cytokines (such as IL-10) and reducing levels of pro-inflammatory cytokines such as TNF- $\alpha$, IL-6 and IL-1 $\beta$ [24]. It can, therefore, be hypothesized that suppression of testosterone levels might be one of the reasons for the large difference in terms of mortality and hospitalization rate between males and females and might also explain why SARS-CoV-2 most commonly infects old men.

On the other hand, androgens seem to play a pivotal role in COVID-19 by promoting the transcription of the transmembrane protease, serine 2 (TMPRSS2) gene. The encoded protein primes the spike protein of SARS-CoV-2, therefore, impairing antibody response and facilitating the fusion between the virus and the host cells [25]. This hypothesis could explain the higher prevalence of COVID-19 in men, although it would fail to explain the rationale for the higher mortality rates, as well as the worse clinical outcomes, for elderly patients.

Additional studies would, therefore, be needed to understand whether testosterone treatment might be beneficial or deleterious for the clinical course of the disease. However, independently of whether testosterone is a friend or foe for COVID-19, it should be acknowledged that the testis is a target for SARS-CoV-2 and the possibility for long-lasting consequences on the endocrine function exists, even for recovered patients.

\section{COVID-19 and the endothelium}

Solid evidence accumulated in the last decades support the notion that erectile function is an excellent surrogate marker of systemic health in general, and vascular performance in particular [26], sharing plenty of risk factors with cardiovascular disease. This is described by the equation $\mathrm{ED}=\mathrm{ED}$ (endothelial dysfunction equals erectile dysfunction, and vice versa) [27]. Vascular integrity is necessary for erectile function [28], and vascular damage associated with COVID-19 is likely to affect the fragile vascular bed of the penis, resulting in impaired erectile function [5, 7]. COVID-19 features a state of hyperinflammation promoted by TNF- $\alpha$, IL- 6 and IL- $1 \beta$ [29]; the same inflammatory cytokines have been associated with clinical progression 
of sexual dysfunction [30]. It is worth noticing that the pro-inflammatory cytokines are also closely tied to testosterone levels: as previously stated, hypogonadal patients have higher concentrations of TNF- $\alpha$, IL- 6 and IL- $1 \beta$ as a result of impaired suppression. This ultimately worsens the endothelial dysfunction, further impairing erectile function. However, whether testosterone replacement therapy (TRT) would improve endothelial function is still debated, while largely beneficial in the treatment of hypogonadal men, TRT has known harmful effects if inappropriately prescribed [31], and a meta-analysis study did not find any conclusive evidence of a potentially therapeutic effect of testosterone administration, neither acute nor chronic, on endothelial function [32]. While erection is - of course-a trivial matter for patients in Intensive Care Units (ICUs), there is reason to suspect that impaired vascular function might persist in COVID-19 survivors and even become a public health issue in the next few months. Moreover, given that erectile function is a predictor of heart disease [33, 34], investigating whether COVID-19 patients develop ED might also be a good surrogate marker of general cardiovascular function, improving patient care and quality of life.

\section{A COVID eclipse of the heart: potential for cardiovascular burden}

Besides the effects on endothelium, SARS-CoV-2 infection can also dramatically affect the heart and exacerbate underlying cardiovascular conditions. Reports of myocarditis in COVID-19 patients have piled up in the last months [35-37]; similarly, arrhythmias and acute cardiovascular events have been described in other coronavirus and influenza epidemics [38-40] and are likely to be expected for SARS-CoV-2 as well [41]. COVID-19 survivors are, therefore, more likely to develop severe cardiovascular consequences. However, treatment is not exempt from possible side effects, among which sexual dysfunctions are remarkably common. Drugs such as $\beta$-blockers and antihypertensive agents, routinely used in COVID-19 patients, have the potential to impair sexual function [41]; therefore, both the cardiovascular consequences and their treatment might ease progression from subclinical to a clinically overt ED [42, 43].

It is also worth mentioning that several cardiovascular risk factors involved in sexual dysfunctions, such as smoking [44], diabetes [45] and hyperhomocysteinemia [46-49], are also possible predictors of worse outcomes in COVID-19 patients.

Additionally, as stated in the III Princeton Consensus Panel [50], sexual activity should be delayed until the cardiac condition has been stabilized in high-risk patients. Such patients include those with uncontrolled hypertension, recent myocardial infarction or high-risk arrhythmia, which are all conditions closely associated with COVID-19 [51].

\section{Reproductive health and COVID-19}

Another reason for worry lies in the reported testicular damage from COVID-19 infection. In fact, ACE2 is highly expressed in the testis, suggesting the possibility of testicular infection since the early stage of the disease [52]. Being expressed in both Sertoli and Leydig cells [18, 53], ACE2 plays key roles in spermatogenesis and in the regulation of steroidogenesis. Due to the involvement of Sertoli cells, reproductive function might similarly be affected. Additionally, ACE2 is also expressed by spermatogonia, therefore, increasing the risk of SARS-CoV-2 presence in seminal fluid $[54,55]$.

Studies investigating the presence of SARS-CoV-2 in seminal fluid have, for the largest part, found no evidence of the virus [56-59]. However, as other studies have shown different results [60], the topic of reproductive health is still largely debated. In post-mortem examinations, seminiferous tubular injury was reported despite no evidence of the virus in the testis [21]. Identification of SARS-CoV-2 in semen is of the utmost importance, as sperm cryopreservation is an undelayable necessity for many men, such as those who are about to start gonadotoxic treatments [61]. In Italy, cryopreservation procedures for oncological patients have continued during the COVID-19 pandemic, using utmost care to limit the risk of transmission; for non-oncological patients, the prospects of biological parenthood could be compromised as a consequence of delaying diagnostic semen analysis and sperm banking [62]. At the beginning of the pandemic, discontinuation of reproductive care except was recommended by international societies for reproductive medicine, with only the most urgent cases allowed; as containment and safety strategies have mitigated the spread of the disease, several centers for assisted reproductive technology have resumed their activity, although with very precise rules for operators [63, 64].

Further studies should, therefore, be designed with the aim to clarify this point, above all among "COVID-19 asymptomatic" men requiring assisted reproductive technology (ART).

\section{The psychological burden of COVID-19}

Increased rates of post-traumatic stress disorder (PTSD), depression and anxiety are expected in the general population, and even more in COVID-19 survivors, following the pandemic [65-68]. A parallel can be drawn between the psychological consequences of COVID-19 and those coming from similar disasters, such as the $9 / 11$ attacks [69] or earthquakes [70], and similar short- and long-term treatment strategies are, therefore, needed to provide adequate care. Confinement and the illness in itself are both causes of stress; while only a minority of individuals might be more 
vulnerable to psychological trauma, there is no doubt that most people would experience some degree of emotional distress following isolation, social distancing, loss of relatives and friends, difficulties in securing medications, as well as the obvious economic consequences of lockdown. Sexual activity is closely associated with mental and psychological health; it is, therefore, unsurprising that sexual desire and frequency have declined in both genders during this pandemic $[71,72]$. There is, therefore, reason to suspect that psychological suffering might exacerbate pre-existing subclinical sexual dysfunctions [73]. Additionally, the potential for SARS-CoV-2 transmission by kissing might lead to increased distress in the couple [74], with the resulting negative effects on sexual health and on couple dynamics. Additionally, the hypogonadal state reported in COVID-19 could lead to a significant worsening in sexual desire and $\operatorname{mood}[75,76]$.

\section{Pulmonary fibrosis and the effects of hypoxia}

It has been suggested, with on the basis of interesting evidence, that there could be substantial fibrotic consequences following SARS-CoV-2 infection [77, 78]. Indeed, pulmonary fibrosis is a well-acknowledged consequence of acute respiratory distress syndrome (ARDS), with further evidence coming from survivors of the 2003 SARS outbreak (caused by the SARS-CoV) [79, 80]. Pulmonary fibrosis impairs the physiologic lung mechanisms, reducing the pulmonary gas exchange and, therefore, impairing oxygen saturation [81, 82]; functional disability has been proven in ARDS patients several years after the acute phase of the disease [83]. There is currently no evidence concerning the possible long-term impairment of lung function following SARS-CoV-2 infection; however, considering the scale of the current pandemic and the similarities between SARSCoV and SARS-CoV-2 [84], there is sufficient reason to suspect a high rate of fibrotic lung function abnormalities in COVID-19 survivors. In such patients, the impaired oxygen saturation could impair erectile function; some evidence in support comes from animal models $[85,86]$ as well as from clinical reports $[87,88]$. From a pathophysiological standpoint, this is hardly surprising, as oxygen is one of the substrates required for the synthesis of nitric oxide (NO) by the enzyme NO synthase, whose activity is severely blunted in hypoxia [87].

\section{Phosphodiesterase-5 inhibitors in COVID-19}

Phosphodiesterase-5 (PDE-5) belongs to the PDE superfamily of enzymes, the last step of the NO/cGMP/PDE pathway and is one of the key elements in drug treatment of ED. $\mathrm{NO}$ activates guanylate cyclase in responsive cells, such as endothelial cells, resulting in increased concentrations of the second messenger cGMP (cyclic guanosine monophosphate), which in turn induces relaxation of smooth muscle. PDE acts downstream and reduces effects of cGMP by catalyzing its degradation: PDE inhibitors prevent degradation of cGMP, resulting in prolonged or enhanced action [89].

PDE-5 is highly expressed in vascular smooth muscle cells [90], and, at high concentrations, in those of the penile corpora cavernosa [91]; therefore, thanks to their action and due to their high affinity for the specific type 5 isoform [92], PDE-5 inhibitors have been approved for their use in treatment of ED since 1998. However, a growing body of evidence has also proven their usefulness as therapeutic agents in different conditions due to their anti-inflammatory and antioxidant actions, as reported in diabetes [93], hypertension and chronic kidney disease [94]. Sildenafil, the first PDE-5 inhibitor approved for the treatment of ED following its serendipitous discovery [95], has also been investigated as a treatment for COVID-19 patients; indeed, Sildenafil improves pulmonary hemodynamics, as shown in idiopathic pulmonary fibrosis [96], by reducing vascular resistance and remodeling in the pulmonary circulation [97]. Additionally, by inhibiting neointimal formation and platelet aggregation, sildenafil also might prove beneficial in regard to the risk of vascular injury and thrombotic complications in COVID-19 patients [98]. Evidence from new trials will prove fundamental to assess the clinical benefits of PDE-5 inhibition on the overall burden of COVID-19 [99].

\section{Conclusions}

In conclusion, there is quite enough reason to suspect that male sexual and reproductive health could be affected in the survivors, by the sequelae of the COVID-19, both in the short and long terms (Fig. 1). Erectile function, as a surrogate marker of cardiovascular/pulmonary health, could also become extremely valuable as a quick and inexpensive firstline assessment of the pulmonary and cardiovascular complications for COVID-19 survivors. In this regard, evidence coming from diagnostic procedures, such as penile colordoppler ultrasound [43] and hypothalamic-pituitary-testicular axis evaluation [100], will be necessary to assess the extent to which COVID-19 has been able to impair erectile, and finally vascular, function, the former being an efficient predictor of complete restitutio ad integrum. Additionally, 


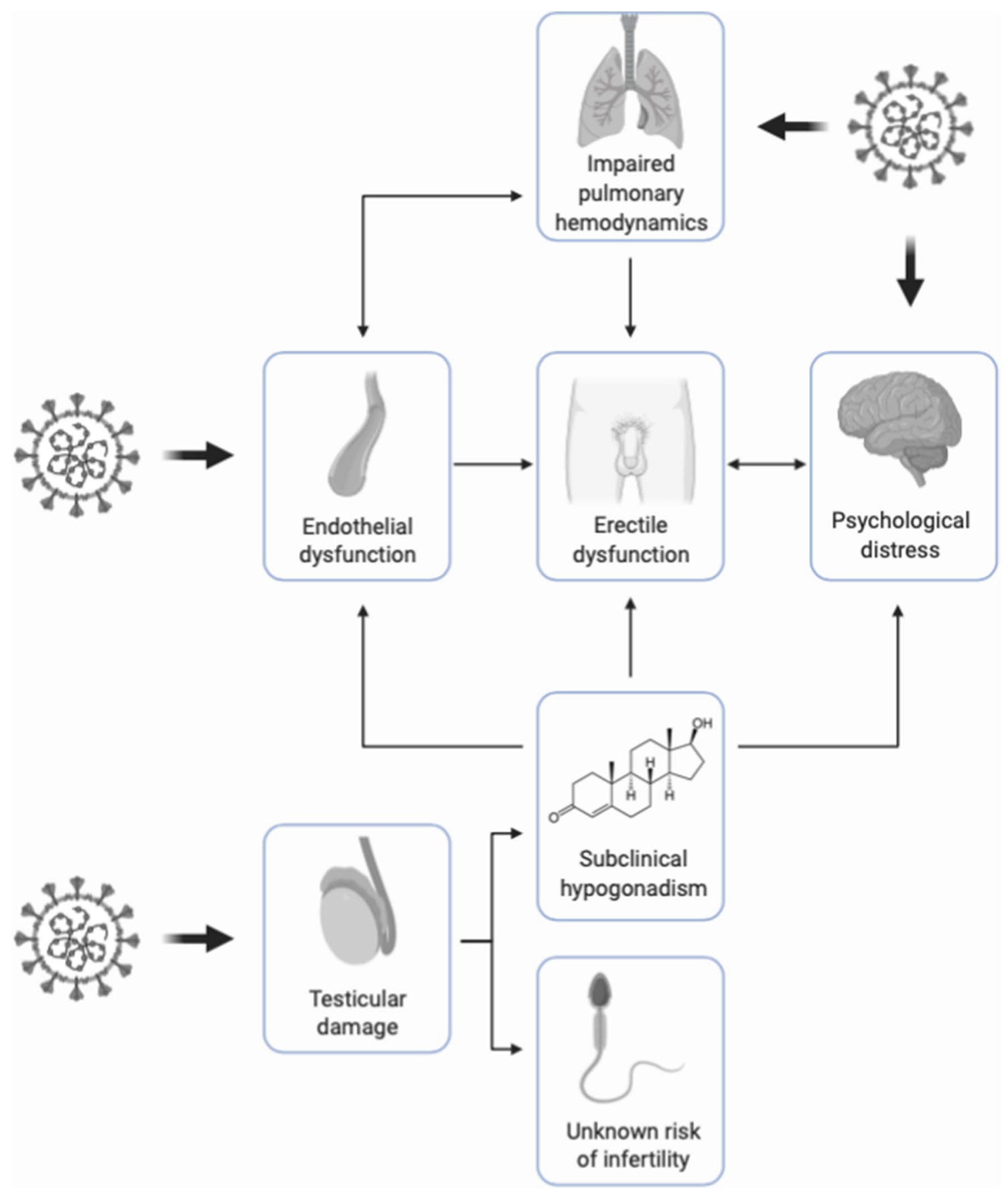

Fig. 1 Graphical overview of the involvement of SARS-CoV-2 in the pathogenesis of erectile dysfunction

tailored psychological interventions would be necessary to adequately support patients who develop sexual dysfunction consequently to the containment measures.

Acknowledgements Open access funding provided by Universitá degli Studi di Roma Tor Vergata within the CRUI-CARE Agreement. The authors are in debt with Dr. Tarek Hassan (Pfizer, New York, $\mathrm{NY}$ ) for discussion on the role of PDE5 and of PDE5i in COVID19 management. This paper is partially supported by the PRIN Grant \#2017S9KTNE_002.

\section{Compliance with ethical standards}

Conflict of interest The authors declare that they have no conflict of interest.

Ethical approval This manuscript is a review of the literature and does not contain original research either on animal or on human subjects. 
Research involving human participants and/or animals This article does not contain any studies involving animals and/or human participants performed by any of the authors.

Informed consent For this type of study, informed consent is not required.

Open Access This article is licensed under a Creative Commons Attribution 4.0 International License, which permits use, sharing, adaptation, distribution and reproduction in any medium or format, as long as you give appropriate credit to the original author(s) and the source, provide a link to the Creative Commons licence, and indicate if changes were made. The images or other third party material in this article are included in the article's Creative Commons licence, unless indicated otherwise in a credit line to the material. If material is not included in the article's Creative Commons licence and your intended use is not permitted by statutory regulation or exceeds the permitted use, you will need to obtain permission directly from the copyright holder. To view a copy of this licence, visit http://creativecommons.org/licenses/by/4.0/.

\section{References}

1. Isidori AM, Pofi R, Hasenmajer V, Lenzi A, Pivonello R (2020) Use of glucocorticoids in patients with adrenal insufficiency and COVID-19 infection. Lancet Diabet Endocrinol 8(6):472-473. https://doi.org/10.1016/s2213-8587(20)30149-2

2. Tay MZ, Poh CM, Renia L, MacAry PA, Ng LFP (2020) The trinity of COVID-19: immunity, inflammation and intervention. Nat Rev Immunol 20(6):363-374. https://doi.org/10.1038/s4157 7-020-0311-8

3. Jose RJ, Manuel A (2020) COVID-19 cytokine storm: the interplay between inflammation and coagulation. Lancet Respir Med 8(6):e46-e47. https://doi.org/10.1016/s2213-2600(20)30216-2

4. Sun X, Wang T, Cai D, Hu Z, Chen J, Liao H et al (2020) Cytokine storm intervention in the early stages of COVID19 pneumonia. Cytokine Growth Factor Rev. https://doi. org/10.1016/j.cytogfr.2020.04.002

5. Liu PP, Blet A, Smyth D, Li H (2020) The science underlying COVID-19: implications for the cardiovascular system. Circulation. https://doi.org/10.1161/CIRCULATIONAHA.120.047549

6. Menter T, Haslbauer JD, Nienhold R, Savic S, Hopfer H, Deigendesch N et al (2020) Post-mortem examination of COVID19 patients reveals diffuse alveolar damage with severe capillary congestion and variegated findings of lungs and other organs suggesting vascular dysfunction. Histopathology. https://doi. org/10.1111/his.14134

7. Varga Z, Flammer AJ, Steiger P, Haberecker M, Andermatt R, Zinkernagel AS et al (2020) Endothelial cell infection and endotheliitis in COVID-19. Lancet 395(10234):1417-1418. https ://doi.org/10.1016/S0140-6736(20)30937-5

8. Lodigiani C, Iapichino G, Carenzo L, Cecconi M, Ferrazzi P, Sebastian $\mathrm{T}$ et al (2020) Venous and arterial thromboembolic complications in COVID-19 patients admitted to an academic hospital in Milan, Italy. Thromb Res 191:9-14. https://doi. org/10.1016/j.thromres.2020.04.024

9. Sardu C, Gambardella J, Morelli MB, Wang X, Marfella R, Santulli G (2020) Hypertension, thrombosis, kidney failure, and diabetes: is COVID-19 an endothelial disease? A comprehensive evaluation of clinical and basic evidence. J Clin Med 9:5. https:// doi.org/10.3390/jcm9051417

10. Lovren F, Pan Y, Quan A, Teoh H, Wang G, Shukla PC et al (2008) Angiotensin converting enzyme-2 confers endothelial protection and attenuates atherosclerosis. Am J Physiol Heart Circ Physiol 295(4):H1377-1384. https://doi.org/10.1152/ajphe art.00331.2008

11. Sluimer JC, Gasc JM, Hamming I, van Goor H, Michaud A, van den Akker LH et al (2008) Angiotensin-converting enzyme 2 (ACE2) expression and activity in human carotid atherosclerotic lesions. J Pathol 215(3):273-279. https://doi.org/10.1002/ path.2357

12. Zhang H, Penninger JM, Li Y, Zhong N, Slutsky AS (2020) Angiotensin-converting enzyme 2 (ACE2) as a SARS-CoV-2 receptor: molecular mechanisms and potential therapeutic target. Intensive Care Med 46(4):586-590. https://doi.org/10.1007/ s00134-020-05985-9

13. Jung F, Kruger-Genge A, Franke RP, Hufert F, Kupper JH (2020) COVID-19 and the endothelium. Clin Hemorheol Microcirc 1:5. https://doi.org/10.3233/CH-209007

14. Pons S, Fodil S, Azoulay E, Zafrani L (2020) The vascular endothelium: the cornerstone of organ dysfunction in severe SARS-CoV-2 infection. Crit Care 24(1):353. https://doi. org/10.1186/s13054-020-03062-7

15. COVID-19 Map. Johns Hopkins Coronavirus Research Center https://coronavirus.jhu.edu/map.html. Accessed 30 May 2020

16. Vittori A, Lerman J, Cascella M, Gomez-Morad AD, Marchetti G, Marinangeli F, Picardo SG (2020) COVID-19 pandemic ARDS survivors: pain after the Storm? Anesth Analg. https:// doi.org/10.1213/ANE.0000000000004914

17. Caruso P, Longo M, Esposito K, Maiorino MI (2020) Type 1 diabetes triggered by COVID-19 pandemic: a potential outbreak? Diabetes Res Clin Pract 164:108219. https://doi.org/10.1016/j. diabres.2020.108219

18. Douglas GC, O'Bryan MK, Hedger MP, Lee DK, Yarski MA, Smith AI, Lew RA (2004) The novel angiotensin-converting enzyme (ACE) homolog, ACE2, is selectively expressed by adult Leydig cells of the testis. Endocrinology 145(10):4703-4711. https://doi.org/10.1210/en.2004-0443

19. Ma L, Xie W, Li D, Shi L, Mao Y, Xiong Y, Zhang Y, Zhang M (2020) Effect of SARS-CoV-2 infection upon male gonadal function: a single center-based study. MedRxiv 200:37-67. https ://doi.org/10.1101/2020.03.21.20037267

20. Pal R, Banerjee M (2020) COVID-19 and the endocrine system: exploring the unexplored. J Endocrinol Invest. https://doi. org/10.1007/s40618-020-01276-8

21. Yang M, Chen S, Huang B, Zhong JM, Su H, Chen YJ et al (2020) Pathological findings in the testes of COVID-19 patients: clinical implications. Eur Urol Focus. https://doi. org/10.1016/j.euf.2020.05.009

22. Rastrelli G, Di Stasi V, Inglese F, Beccaria M, Garuti M, Di Costanzo D et al (2020) Low testosterone levels predict clinical adverse outcomes in SARS-CoV-2 pneumonia patients. Andrology. https://doi.org/10.1111/andr.12821

23. Isidori AM, Buvat J, Corona G, Goldstein I, Jannini EA, Lenzi A et al (2014) A critical analysis of the role of testosterone in erectile function: from pathophysiology to treatment-a systematic review. Eur Urol 65(1):99-112. https://doi.org/10.1016/j. eururo.2013.08.048

24. Mohamad NV, Wong SK, Wan Hasan WN, Jolly JJ, NurFarhana MF, Ima-Nirwana S, Chin KY (2019) The relationship between circulating testosterone and inflammatory cytokines in men. Aging Male 22(2):129-140. https://doi. org/10.1080/13685538.2018.1482487

25. Wambier CG, Goren A, Vano-Galvan S, Ramos PM, Ossimetha A, Nau G, Herrera S, McCoy J (2020) Androgen sensitivity gateway to COVID-19 disease severity. Drug Dev Res. https ://doi.org/10.1002/ddr.21688

26. Jannini EA (2017) SM = SM: The interface of systems medicine and sexual medicine for facing non-communicable 
diseases in a gender-dependent manner. Sex Med Rev 5(3):349-364. https://doi.org/10.1016/j.sxmr.2017.04.002

27. Guay AT (2007) ED2: erectile dysfunction = endothelial dysfunction. Endocrinol Metab Clin North Am 36(2):453-463. https://doi.org/10.1016/j.ecl.2007.03.007

28. Yafi FA, Jenkins L, Albersen M, Corona G, Isidori AM, Goldfarb S et al (2016) Erectile dysfunction. Nat Rev Dis Primers 2:16003. https://doi.org/10.1038/nrdp.2016.3

29. Pedersen SF, Ho YC (2020) SARS-CoV-2: a storm is raging. J Clin Invest 130(5):2202-2205. https://doi.org/10.1172/JCI13 7647

30. Maiorino MI, Bellastella G, Giugliano D, Esposito K (2018) From inflammation to sexual dysfunctions: a journey through diabetes, obesity, and metabolic syndrome. J Endocrinol Invest 41(11):1249-1258. https://doi.org/10.1007/s40618-018-0872-6

31. Sansone A, Sansone M, Lenzi A, Romanelli F (2017) Testosterone replacement therapy: the emperor's new clothes. Rejuvenation Res 20(1):9-14. https://doi.org/10.1089/rej.2016.1818

32. Sansone A, Rastrelli G, Cignarelli A, de Rocco PM, Condorelli RA, Giannetta E et al (2019) Effect of treatment with testosterone on endothelial function in hypogonadal men: a systematic review and meta-analysis. Int J Impot Res. https:// doi.org/10.1038/s41443-019-0163-6

33. Kloner RA (2008) Erectile dysfunction as a predictor of cardiovascular disease. Int J Impot Res 20(5):460-465. https:// doi.org/10.1038/ijir.2008.20

34. Corona G, Forti G, Maggi M (2008) Why can patients with erectile dysfunction be considered lucky? The association with testosterone deficiency and metabolic syndrome. Aging Male 11(4):193-199. https://doi.org/10.1080/13685530802468497

35. Xu Z, Shi L, Wang Y, Zhang J, Huang L, Zhang C et al (2020) Pathological findings of COVID-19 associated with acute respiratory distress syndrome. Lancet Respir Med 8(4):420-422. https://doi.org/10.1016/S2213-2600(20)30076-X

36. Inciardi RM, Lupi L, Zaccone G, Italia L, Raffo M, Tomasoni $\mathrm{D}$ et al (2020) Cardiac involvement in a patient with coronavirus disease 2019 (COVID-19). JAMA Cardiol. https://doi. org/10.1001/jamacardio.2020.1096

37. Hu H, Ma F, Wei X, Fang Y (2020) Coronavirus fulminant myocarditis saved with glucocorticoid and human immunoglobulin. Eur Heart J. https://doi.org/10.1093/eurheartj/ehaa190

38. Madjid M, Miller CC, Zarubaev VV, Marinich IG, Kiselev OI, Lobzin YV, Filippov AE, Casscells SW 3rd (2007) Influenza epidemics and acute respiratory disease activity are associated with a surge in autopsy-confirmed coronary heart disease death: results from 8 years of autopsies in 34,892 subjects. Eur Heart $\mathbf{J}$ 28(10):1205-1210. https://doi.org/10.1093/eurheartj/ehm035

39. Kwong JC, Schwartz KL, Campitelli MA, Chung H, Crowcroft NS, Karnauchow T et al (2018) Acute myocardial infarction after laboratory-confirmed influenza infection. N Engl J Med 378(4):345-353. https://doi.org/10.1056/NEJMoa1702090

40. Madjid M, Connolly AT, Nabutovsky Y, Safavi-Naeini P, Razavi M, Miller CC (2019) Effect of high influenza activity on risk of ventricular arrhythmias requiring therapy in patients with implantable cardiac defibrillators and cardiac resynchronization therapy defibrillators. Am J Cardiol 124(1):44-50. https://doi. org/10.1016/j.amjcard.2019.04.011

41. Madjid M, Safavi-Naeini P, Solomon SD, Vardeny O (2020) Potential effects of coronaviruses on the cardiovascular system: a review. JAMA Cardiol. https://doi.org/10.1001/jamacardio .2020 .1286

42. Jannini EA, Lenzi A, Isidori A, Fabbri A (2006) Subclinical erectile dysfunction: proposal for a novel taxonomic category in sexual medicine. J Sex Med 3(5):787-794. https://doi.org/10.11 11/j.1743-6109.2006.00287.x
43. Mulhall JP, Giraldi A, Hackett G, Hellstrom WJG, Jannini EA, Rubio-Aurioles E, Trost L, Hassan TA (2018) The 2018 revision to the process of care model for management of erectile dysfunction. J Sex Med 15(10):1434-1445. https://doi.org/10.1016/j. jsxm.2018.05.021

44. Corona G, Sansone A, Pallotti F, Ferlin A, Pivonello R, Isidori AM, Maggi M, Jannini EA (2020) People smoke for nicotine, but lose sexual and reproductive health for tar: a narrative review on the effect of cigarette smoking on male sexuality and reproduction. J Endocrinol Invest. https://doi.org/10.1007/s40618-02001257-x

45. Filardi T, Morano S (2020) COVID-19: is there a link between the course of infection and pharmacological agents in diabetes? J Endocrinol Invest. https://doi.org/10.1007/s40618-020-01318 $-1$

46. Ponti G, Ruini C, Tomasi A (2020) Homocysteine as a potential predictor of cardiovascular risk in patients with COVID-19. Med Hypotheses 143:14. https://doi.org/10.1016/j.mehy.2020.109859

47. Sansone A, Cignarelli A, Sansone M, Romanelli F, Corona G, Gianfrilli D, Isidori A, Giorgino F, Lenzi A (2018) Serum homocysteine levels in men with and without erectile dysfunction: a systematic review and meta-analysis. Int J Endocrinol 2018:7424792. https://doi.org/10.1155/2018/7424792

48. Lombardo F, Sgro P, Gandini L, Dondero F, Jannini EA, Lenzi A (2004) Might erectile dysfunction be due to the thermolabile variant of methylenetetrahydrofolate reductase? J Endocrinol Invest 27(9):883-885. https://doi.org/10.1007/BF03346286

49. Sansone M, Sansone A, Romano M, Seraceno S, Di Luigi L, Romanelli F (2018) Folate: a possible role in erectile dysfunction? Aging Male 21(2):116-120. https://doi.org/10.1080/13685 538.2017.1404022

50. Nehra A, Jackson G, Miner M, Billups KL, Burnett AL, Buvat J et al (2012) The Princeton III consensus recommendations for the management of erectile dysfunction and cardiovascular disease. Mayo Clin Proc 87(8):766-778. https://doi.org/10.1016/j.mayoc p.2012.06.015

51. Lang JP, Wang X, Moura FA, Siddiqi HK, Morrow DA, Bohula EA (2020) A current review of COVID-19 for the cardiovascular specialist. Am Heart J 226:29-44. https://doi.org/10.1016/j. ahj.2020.04.025

52. Younis JS, Abassi Z, Skorecki K (2020) Is there an impact of the COVID-19 pandemic on male fertility? The ACE2 connection. Am J Physiol Endocrinol Metab 318(6):E878-E880. https://doi. org/10.1152/ajpendo.00183.2020

53. Wang S, Zhou X, Zhang T, Wang Z (2020) The need for urogenital tract monitoring in COVID-19. Nat Rev Urol 17(6):314-315. https://doi.org/10.1038/s41585-020-0319-7

54. Wang Z, Xu X (2020) scRNA-seq profiling of human testes reveals the presence of the ACE2 receptor, a target for SARSCoV-2 infection in spermatogonia Leydig and Sertoli. Cells 9:4. https://doi.org/10.3390/cells9040920

55. Verma S, Saksena S, Sadri-Ardekani H (2020) ACE2 receptor expression in testes: implications in COVID-19 pathogenesis. Biol Reprod. https://doi.org/10.1093/biolre/ioaa080

56. Paoli D, Pallotti F, Colangelo S, Basilico F, Mazzuti L, Turriziani O, Antonelli G, Lenzi A, Lombardo F (2020) Study of SARS-CoV-2 in semen and urine samples of a volunteer with positive naso-pharyngeal swab. J Endocrinol Invest. https://doi. org/10.1007/s40618-020-01261-1

57. Paoli D, Pallotti F, Turriziani O, Mazzuti L, Antonelli G, Lenzi A, Lombardo F (2020) SARS-CoV-2 Presence in seminal fluid: myth or reality. Andrology. https://doi.org/10.1111/andr.12825

58. Song C, Wang Y, Li W, Hu B, Chen G, Xia P et al (2020) Absence of 2019 novel coronavirus in semen and testes of 
COVID-19 patients. Biol Reprod. https://doi.org/10.1093/biolr e/ioaa050

59. Pan F, Xiao X, Guo J, Song Y, Li H, Patel DP et al (2020) No evidence of severe acute respiratory syndrome-coronavirus 2 in semen of males recovering from coronavirus disease 2019. Fertil Steril 113(6):1135-1139. https://doi.org/10.1016/j.fertnstert .2020 .04 .024

60. Li D, Jin M, Bao P, Zhao W, Zhang S (2020) Clinical characteristics and results of semen tests among men with coronavirus disease 2019. JAMA Netw Open 3(5):e208292. https://doi. org/10.1001/jamanetworkopen.2020.8292

61. Corona G, Baldi E, Isidori AM, Paoli D, Pallotti F, De Santis L et al (2020) SARS-CoV-2 infection, male fertility and sperm cryopreservation: a position statement of the Italian society of andrology and sexual medicine (SIAMS) (Societa Italiana di Andrologia e Medicina della Sessualita). J Endocrinol Invest. https://doi.org/10.1007/s40618-020-01290-w

62. Esteves SC, Lombardo F, Garrido N, Alvarez J, Zini A, Colpi GM et al (2020) SARS-CoV-2 pandemic and repercussions for male infertility patients: a proposal for the individualized provision of andrological services. Andrology. https://doi.org/10.1111/ andr. 12809

63. De Santis L, Anastasi A, Cimadomo D, Klinger FG, Licata E, Pisaturo V, Sosa Fernandez L, Scarica C (2020) COVID-19: the perspective of Italian embryologists managing the IVF laboratory in pandemic emergency. Hum Reprod 35(4):1004-1005. https://doi.org/10.1093/humrep/deaa074

64. COVID-19 and Human Reproduction Joint Statement: ASRM/ ESHRE/IFFS. https://www.asrm.org/news-and-publications/ covid-19/statements/covid-19-and-human-reproduction-joint -statement-asrmeshreiffs/. Accessed 28 June 2020

65. Dutheil F, Mondillon L, Navel V (2020) PTSD as the second tsunami of the SARS-Cov-2 pandemic. Psychol Med 1:2. https ://doi.org/10.1017/S0033291720001336

66. Shuja KH, Aqeel M, Jaffar A, Ahmed A (2020) COVID-19 pandemic and impending global mental health implications. Psychiatr Danub 32(1):32-35. https://doi.org/10.24869/psyd.2020.32

67. Liu X, Luo WT, Li Y, Li CN, Hong ZS, Chen HL, Xiao F, Xia JY (2020) Psychological status and behavior changes of the public during the COVID-19 epidemic in China. Infect Dis Poverty 9(1):58. https://doi.org/10.1186/s40249-020-00678-3

68. Gonzalez-Sanguino C, Ausin B, Castellanos MA, Saiz J, LopezGomez A, Ugidos C, Munoz M (2020) Mental health consequences during the initial stage of the 2020 COronavirus pandemic (COVID-19) in Spain. Brain Behav Immun. https://doi. org/10.1016/j.bbi.2020.05.040

69. DePierro J, Lowe S, Katz C (2020) Lessons learned from 9/11: mental health perspectives on the COVID-19 pandemic. Psychiatry Res 288:113024. https://doi.org/10.1016/j.psychres.2020.113024

70. Ciocca G, Carosa E, Stornelli M, Limoncin E, Gravina GL, Iannarelli $\mathrm{R}$ et al (2014) Post-traumatic stress disorder, coping strategies and type 2 diabetes: psychometric assessment after L'Aquila earthquake. Acta Diabetol 52(3):513-521. https://doi.org/10.1007/ s00592-014-0686-8

71. Li W, Li G, Xin C, Wang Y, Yang S (2020) Changes in sexual behaviors of young women and men during the coronavirus disease 2019 outbreak: a convenience sample from the epidemic area. J Sex Med. https://doi.org/10.1016/j.jsxm.2020.04.380

72. Yuksel B, Ozgor F (2020) Effect of the COVID-19 pandemic on female sexual behavior. Int J Gynaecol Obstet. https://doi. org/10.1002/ijgo.13193

73. Miranda EP, Nascimento B, Torres LO, Glina S (2020) Challenges in the practice of sexual medicine in the time of COVID-19. J Sex Med. https://doi.org/10.1016/j.jsxm.2020.05.013

74. Aversa A, Jannini EA (2020) COVID-19, or the triumph of monogamy? Minerva Endocrinol. https://doi.org/10.23736/S0391 $-1977.20 .03207-1$
75. Corona G, Rastrelli G, Ricca V, Jannini EA, Vignozzi L, Monami $\mathrm{M}$ et al (2013) Risk factors associated with primary and secondary reduced libido in male patients with sexual dysfunction. J Sex Med 10(4):1074-1089. https://doi.org/10.1111/jsm.12043

76. Saad F, Aversa A, Isidori AM, Zafalon L, Zitzmann M, Gooren L (2011) Onset of effects of testosterone treatment and time span until maximum effects are achieved. Eur J Endocrinol 165(5):675-685. https://doi.org/10.1530/eje-11-0221

77. Spagnolo P, Balestro E, Aliberti S, Cocconcelli E, Biondini D, Casa GD, Sverzellati N, Maher TM (2020) Pulmonary fibrosis secondary to COVID-19: a call to arms? Lancet Respir Med. https://doi. org/10.1016/S2213-2600(20)30222-8

78. George PM, Wells AU, Jenkins RG (2020) Pulmonary fibrosis and COVID-19: the potential role for antifibrotic therapy. Lancet Respir Med. https://doi.org/10.1016/S2213-2600(20)30225-3

79. Gralinski L, Bankhead A, Jeng S, Menachery V, Proll S, Belisle SE et al (2013) Mechanisms of severe acute respiratory syndrome coronavirus-induced acute lung injury. mBio 4:4-37

80. Chan KS, Zheng JP, Mok YW, Li YM, Liu YN, Chu CM, Ip MS (2003) SARS: prognosis, outcome and sequelae. Respirology 8:S36-40. https://doi.org/10.1046/j.1440-1843.2003.00522.x

81. Graney BA, Wamboldt FS, Baird S, Churney T, Fier K, Korn M, McCormick M, Vierzba T, Swigris JJ (2017) Looking ahead and behind at supplemental oxygen: a qualitative study of patients with pulmonary fibrosis. Heart Lung 46(5):387-393. https://doi. org/10.1016/j.hrtlng.2017.07.001

82. Cavezzi A, Troiani E, Corrao S (2020) COVID-19: hemoglobin, iron, and hypoxia beyond inflammation. A Narrat Rev Clin Pract 10(2):1271. https://doi.org/10.4081/cp.2020.1271

83. Herridge MS, Tansey CM, Matte A, Tomlinson G, Diaz-Granados N, Cooper A et al (2011) Functional disability 5 years after acute respiratory distress syndrome. N Engl J Med 364(14):1293-1304. https://doi.org/10.1056/NEJMoa1011802

84. Rabaan AA, Al-Ahmed SH, Haque S, Sah R, Tiwari R, Malik YS et al (2020) SARS-CoV-2, SARS-CoV, and MERS-COV: a comparative overview. Infez Med 28(2):174-184

85. Yu DP, Liu XH, Wei AY (2015) Effect of chronic hypoxia on penile erectile function in rats. Genet Mol Res 14(3):10482-10489. https ://doi.org/10.4238/2015.September.8.9

86. Vignozzi L, Morelli A, Filippi S, Vannelli GB, Mungai S, Marini M, Boddi V, Forti G, Maggi M (2008) Effect of sildenafil administration on penile hypoxia induced by cavernous neurotomy in the rat. Int J Impot Res 20(1):60-67. https://doi.org/10.1038/ sj.ijir.3901596

87. Verratti V, Di Giulio C, Berardinelli F, Pellicciotta M, Di Francesco S, Iantorno R, Nicolai M, Gidaro S, Tenaglia R (2007) The role of hypoxia in erectile dysfunction mechanisms. Int J Impot Res 19(5):496-500. https://doi.org/10.1038/sj.ijir.3901560

88. Padmanabhan P, McCullough AR (2007) Penile oxygen saturation in the flaccid and erect penis in men with and without erectile dysfunction. J Androl 28(2):223-228. https://doi.org/10.2164/jandr ol.106.001313

89. Dolci S, Belmonte A, Santone R, Giorgi M, Pellegrini M, Carosa E, Piccione E, Lenzi A, Jannini EA (2006) Subcellular localization and regulation of type-1C and type-5 phosphodiesterases. Biochem Biophys Res Commun 341(3):837-846. https://doi.org/10.1016/j. bbrc.2006.01.035

90. Cesarini V, Pisano C, Rossi G, Balistreri CR, Botti F, Antonelli G, Ruvolo G, Jannini EA, Dolci S (2019) Regulation of PDE5 expression in human aorta and thoracic aortic aneurysms. Sci Rep 9:1. https://doi.org/10.1038/s41598-019-48432-6

91. Morelli A, Filippi S, Mancina R, Luconi M, Vignozzi L, Marini M et al (2004) Androgens regulate phosphodiesterase type 5 expression and functional activity in corpora cavernosa. Endocrinology 145(5):2253-2263. https://doi.org/10.1210/en.2003-1699 
92. Seftel AD (2004) Phosphodiesterase type 5 inhibitor differentiation based on selectivity, pharmacokinetic, and efficacy profiles. Clin Cardiol 27:14-19. https://doi.org/10.1002/clc.4960271305

93. Santi D, Giannetta E, Isidori AM, Vitale C, Aversa A, Simoni M (2015) Therapy of endocrine disease. Effects of chronic use of phosphodiesterase inhibitors on endothelial markers in type 2 diabetes mellitus: a meta-analysis. Eur J Endocrinol 172(3):103-114. https://doi.org/10.1530/EJE-14-0700

94. Brown KE, Dhaun N, Goddard J, Webb DJ (2014) Potential therapeutic role of phosphodiesterase type 5 inhibition in hypertension and chronic kidney disease. Hypertension 63(1):5-11. https://doi. org/10.1161/HYPERTENSIONAHA.113.01774

95. Goldstein I, Burnett AL, Rosen RC, Park PW, Stecher VJ (2019) The Serendipitous story of sildenafil: an unexpected oral therapy for erectile dysfunction. Sex Med Rev 7(1):115-128. https://doi. org/10.1016/j.sxmr.2018.06.005

96. Rochwerg B, Neupane B, Zhang Y, Garcia CC, Raghu G, Richeldi L, Brozek J, Beyene J, Schunemann H (2016) Treatment of idiopathic pulmonary fibrosis: a network meta-analysis. BMC Med 14(1):18. https://doi.org/10.1186/s12916-016-0558-x

97. Prasad S, Wilkinson J, Gatzoulis MA (2000) Sildenafil in primary pulmonary hypertension. N Engl J Med 343(18):1342-1342. https ://doi.org/10.1056/nejm200011023431814
98. Yang HM, Jin S, Jang H, Kim JY, Lee JE, Kim J, Kim HS (2019) Sildenafil reduces neointimal hyperplasia after angioplasty and inhibits platelet aggregation via activation of cGMP-dependent protein kinase. Sci Rep 9(1):7769. https://doi.org/10.1038/s4159 8-019-44190-7

99. Isidori AM, Giannetta E, Pofi R, Venneri MA, Gianfrilli D, Campolo F, Mastroianni CM, Lenzi A, d'Ettorre G (2020) Targeting the NO-cGMP-PDE5 pathway in COVID-19 infection. Andrology. https://doi.org/10.1111/andr.12837

100. Sansone A, Romanelli F, Gianfrilli D, Lenzi A (2014) Endocrine evaluation of erectile dysfunction. Endocrine 46(3):423-430. https ://doi.org/10.1007/s12020-014-0254-6

Publisher's Note Springer Nature remains neutral with regard to jurisdictional claims in published maps and institutional affiliations. 